\title{
Finansal Başarısızlık Riski Taşıyan ile Taşımayan İşletmelerin Finansal Oranlarının Karşılaştırmalı Analizi: Borsa İstanbul Turizm İşletmelerinde Bir Araştırma
}

\section{Comparative Financial Ratio Analysis of Companies at Risk of Financial Failure and Companies at Non-Risk of Financial Failure: A Research on Borsa İstanbul Tourism Companies}

\author{
Doç.Dr. Erdinç KARADENIZ \\ Mersin Üniversitesi \\ Turizm Fakültesi \\ E-posta: ekaradeniz@mersin.edu.tr
}

Cemile ÖCEK

Mersin Üniversitesi

Sosyal Bilimler Enstitüsü

E-posta: cemile_ocek@hotmail.com

Öz

Bu araştırmanın amacı, Borsa İstanbul'da hisseleri işlem gören turizm işletmeleri içinde finansal başarısızlık riski taşıyanlar ile taşımayanların finansal oranları arasında istatistiksel olarak anlamlı bir farklılık olup olmadığının belirlenmesidir. Bu bağlamda öncelikle 2012-2017 yılları arasında turizm işletmelerinin finansal başarısızlık riskleri Altman Z Skor modeline göre belirlenmiştir. Daha sonra finansal başarısızlık riski taşıyan ve taşımayan işletmelerin finansal oranları arasında farklılık olup olmadığı Mann Whitney U Testi ile saptanmaya çalışılmıştır. Analiz sonucunda finansal başarısızlık riski taşıyan işletmeler ile finansal başarısızlık riski taşımayan işletmeler arasında cari oran, asit-test oranı, nakit oran, kaldıraç oranı, aktif karlılığı, öz sermaye karlılığı, net kar marjı ve fiyat/kazanç oranı bağlamında istatistiksel olarak anlamlı farklılık olduğu saptanmıştır.

Anahtar Kelimeler: Finansal Başarısızlık Riski, Altman Z Skor Modeli, Rasyo Analizi, Turizm İşletmeleri, Borsa İstanbul.

\begin{abstract}
The aim of this study is to determine whether there is a statistically significant difference in the financial ratios of those who have a risk of financial failure and the ones who do not have a risk of financial failure in the tourism companies listed in Borsa Istanbul. In this context, the financial failure risks of the tourism companies were determined according to the Altman Z Score model between the years 2012-2017. Then, it was tried to be determined by the Mann Whitney U Test whether there is any difference between the financial ratios of the companies which have the risk of financial failure and which do not have the risk of financial failure. As a result of the analysis, it was found that there was a statistically significant difference in terms of current ratio, acid-test ratio, cash ratio, leverage ratio, return on assets, return on equity, net profit margin and price to earnings ratio between the companies with the risk of financial failure and the companies that do not have the risk of financial failure.
\end{abstract}

Key Words: Financial Failure Risk, Altman Z Score Model, Ratio Analysis, Tourism Companies, Borsa İstanbul. 


\section{Giriş}

Son yıllarda küresel ölçekte yaşanan ticaret ve kur savaşlarının derinleşmesi, Brexit süreci ve uluslararası ticarette korumacılık kaygılarının artması birçok gelişmiş ve gelişmekte olan ülke ekonomilerini ve bu ekonomilerde faaliyet gösteren işletmeleri olumsuz etkilemektedir. Bu bağlamda devletler ve işletmeler ekonomik ve finansal bağlamda krizler yaşayabilmektedir. Finansal açıdan işletmelerin finansal başarısızlığa uğramamaları açısından üretim, faaliyet ve finansmanla ilgili maliyet ve giderlerini kontrol altında tutmaları, mevcut ve potansiyel faiz, kur ve likidite risklerini yakından takip etmeleri ve nakit akışları ile karlılıklarını sürdürülebilir hale getirmeleri büyük önem arz etmektedir.

Alacak sigortası şirketi Euler Hermes tarafından hazırlanan ve küresel ölçekte GSYH'nin \%83'ünü oluşturan 43 ülkeyi kapsayan 2019 Küresel İflas Raporunda; 2018 yılında küresel düzeyde işletme iflaslarının bir önceki yıla göre $\% 10$ oranında artış gösterdiği ifade edilmekte ve 2019 yılında da küresel işletme iflaslarının \%6 düzeyinde artacağı tahmin edilmektedir. Raporda, küresel ekonominin 2018'de kaydettiği \%3,1'lik büyüme oranının, 2019'da \%3 gerçekleşeceği ifade edilmektedir. Beklenen küresel GSYH'deki düşüşün, üretim ve finansman maliyetlerinin yükselmesi ve finansmana kolay erişimin sona ermesinin özellikle sabit giderleri yüksek, daha büyük stok ve varlıklara sahip olan ve bu nedenle çalışma sermayesi gereksinimi fazla olan ve yüksek finansal borca sahip işletmelerin kırılganlıklarını arttırdığı raporda vurgulanmaktadır. Yine raporda Türkiye'de 2018 yılında 15.400 olan iflas eden işletme sayısının 2019 yılında 16.200'e yükseleceği ve iflas eden işletme sayısında \%5'lik bir artış olacağı ifade edilmektedir (Euler Hermes, 2019). 2018 yılında Türkiye ekonomisinin büyümesinde gerçekleşen yavaşlama, yaşanan kur artışı ve kur artışına bağlı olarak üretim ve finansman maliyetlerindeki artışı fiyat artışıyla dengeleyememe durumu, işletmelerin finansal durumlarını olumsuz etkilemiş ve konkordatoya giden işletme sayısında da artış gerçekleşmiştir.

II. Dünya Savaşı'nın sona ermesinden sonra turizm sektörü; teknoloji ile ulaşım imkanlarının gelişmesi, harcanabilir gelir ve boş zamanın artması sonucunda yarattığı istihdam, gelir ve katma değerle ve hizmet verdiği insan sayısıyla dünya ekonomilerinin en hızı büyüyen sektörlerinden biri konumuna gelmiştir. Bu sektörde faaliyet gösteren turizm işletmeleri; sabit sermaye yatıımları yoğun olan, enerji, personel ve hammadde giderlerinin her gün yükseldiği, kontrol edilebilen ve edilemeyen risklerin her zaman var olduğu işletmelerdir (Unur, 2000; Unur, 2004; Kandır ve diğ., 2008).

Son yıllarda küresel ölçekte ve Türkiye'de birçok büyük turizm işletmesinin çeşitli nedenlerle finansal sıkıntıya girdiği, iflas ve konkordato başvurusunda bulunduğu veya el değiştirdiği görülebilmektedir. Örneğin Lykia World Antalya ve Lykia World Fethiye'nin sahibi Silkar Turizm'in yaşadığı iflas erteleme süreci veya Starwood Otelcilik Grubu'nun el değiştirme süreci sektörde yaşanan önemli finansal başarısızlık süreçleridir (Karadeniz ve diğ., 2016). Dun \& Bradstreet kuruluşunun 1992-1997 yılları arasındaki işletme başarısızlıklarının sektörler temelinde karşılaştırması sonucunda da, hizmet sektöründen yeme-içme, konaklama ve servis işletmelerinin finansal başarısızlıklarının diğer sektörlere göre çok daha fazla olduğu gözlemlenmiştir (Gu ve Goa, 2000).

Turizm işletmelerinde karşılaşılan finansal başarısızlıklar, turizm sektörünü ve bu bağlamda ülke ekonomilerini olumsuz etkileyebilmektedir. Örneğin yatırım aşamasında sermaye yoğun işletmeler olmasına rağmen işletme aşamasında turizm işletmelerinin emek yoğun olması, bu işletmelerin finansal başarısızlık yaşamaları halinde istihdam 
ettiği işgücünü de azaltmakta ve bu durum ülke ekonomisinde istihdam sorunlarına yol açabilmektedir. Bununla birlikte finansal başarısızlık içinde bulunan turizm işletmeleri, sundukları hizmetin nitelik ve nicelik açısından kalitesini düşürebilmekte ve bu durum turizm sektöründeki iç ve dış talebi olumsuz yönde etkileyebilmektedir. Ayrıca turizm işletmelerinin yaşayacağı finansal başarısızlıklar, ilişki içerisinde bulunduğu diğer işletmelerinde finansal sorun yaşamalarına sebep olabilmektedir. Dolayısıyla turizm işletmeleri özelinde finansal başarısızlık riskinin ölçülmesi ve yönetilmesi hem sektör hem de ülke ekonomisi açısından büyük önem arz etmektedir (Karadeniz ve diğ., 2015; Türksoy, 2007).

$\mathrm{Bu}$ araştırmanın amacı, Borsa İstanbul (BIST) turizm işletmeleri içinde finansal başarısızlık riski içerisinde olanlar ile finansal başarısızlık riski içerisinde olmayan işletmelerin likidite, mali yapı, faaliyet, karlılık ve piyasa performansını gösteren finansal oranlarını incelemek ve bu oranlar arasında anlamlı bir farklılık olup olmadığını istatistiksel olarak belirlemektir. Bu bağlamda öncelikle 2012-2017 yılları arasında turizm işletmelerinin finansal başarısızlık riskleri Altman Z Skor modeline göre hesaplanmıştır. Daha sonra finansal başarısızlık riski taşıyan ve finansal başarısızlık riski taşımayan turizm işletmelerinin finansal oranları arasında farklılık olup olmadığı Mann Whitney $U$ Testi ile saptanmaya çalışıımıştır. Bu bağlamda araştırma altı bölümden oluşmaktadır. İkinci bölümde finansal başarısızlık kavramı tartışılmıştır. Çalışmanın üçüncü bölümünde konuyla ilgili daha önce gerçekleştirilen araştırmalar özetlenmiştir. Dördüncü bölümde araştırmanın verileri ve analizde kullanılan Altman Z Skor modeli, hesaplanan finansal oranlar ve Mann Whitney U Testi hakkında bilgi verilmiştir. Beşinci bölümde araştırma sonucunda saptanan bulgular sunulmuştur. Sonuç bölümünde ise genel bir değerlendirmeye ve önerilere yer verilmeye çalışılmıştır.

\section{Finansal Başarısızlık Kavramı}

Başarısızlık; sektör, ülke, büyüklük ve gelişmişlik düzeylerinden bağımsız olarak, bütün işletmelerin yaşayabileceği bir sorundur. İşletmelerin borçlarını zamanında ödeyememesinden hiç ödenememesine, ticari güvenilirliğini kaybetmesinden iflas sürecine kadar birçok gelişme başarısızlık olarak tanımlanabilmektedir (Aydın ve diğ., 2014). İşletmeler açısından başarısızlık, ekonomik ve finansal olmak üzere iki şekilde meydana gelebilmektedir (Ceylan, 2001). Ekonomik başarısızlık, belirli düzeyde riske sahip bir yatırım alanına yatırılan sermaye üzerinden sağlanan getiri oranının, eşdeğer riske sahip alternatif yatırımlardaki getiri oranından dikkat çekici derecede ve sürekliliği devam eden bir şekilde düşüş göstermesi olarak tanımlanabilmektedir (Özdemir, 2011). Finansal başarısızlık ise ödenmesi gereken kısa vadeli yükümlülüklerin karşılanamaması veya nakit akışlarındaki göstergelerin bu yükümlülüğü karşılayamama durumudur. Diğer bir ifadeyle gerçekleşen nakit akışları değerinin beklenen değerden düşük olmasıdır (Brigham ve Ehrhardt, 2010).

Finansal başarısızlık kavramı ilk defa, uluslararası derecelendirme kuruluşlarından olan Dun \& Bradstreet tarafından tanımlanmıştır. Bu tanıma göre bir işletmenin finansal açıdan başarılı olmadığı sonucuna ulaşılabilmesi için; işletmenin faaliyetlerini durdurması ya da iflas halinde olması, işletmede icra, haciz ya da mülkiyete rehin gibi olayların yaşanması, işletmenin yerine getirilmemiş yükümlülüklerini yerine getirebilmek için çabalamaması gibi durumların gerçekleşmesi gerekmektedir. Bunların yanı sıra işletmeye kayyum atanması ya da yeniden yapılandırma gibi mahkeme süreçlerini yaşıyor olması ve işletmeye borç verenler ile borçların ödeme süreleri ve ödenme durumu ile ilgili anlaşma yapılması durumlarından bir tanesinin bulunması gerektiği öngörülmüştür (Altman ve Hotchkiss, 2006). Genel 
anlamda finansal başarısızlık kavramı, finans teorisinde iflas kavramı yerine kullanılan bir kavram olarak da karşımıza çıkmaktadır (Altman, 1968; Elam, 1975; Warner, 1977; Ohlson, 1980; Clark ve Weinstein, 1983; Casey ve Bartczak, 1985; Hotchkiss, 1995). Çünkü finansal başarısızlık kavramı, iflas kavramına göre daha geniş kapsamlı olduğundan çalışmalardaki örneklemlerin daha geniş tutulmasına imkân vermektedir (Aktaş, 1993).

\section{Literatür}

Konuyla ilgili literatür taraması neticesinde işletmelerin finansal başarısızlığını önceden tahmin etmeye yönelik birçok araştırma bulunduğu görülmektedir. Gerçekleştirilen araştırmalarda öncelikle işletmelerin finansal başarısızlıklarının önceden tahmin edilmesine yönelik modeller geliştirilmeye çalışılmış ve finans teorisinde yer bulan birçok model geliştirilmiştir.

Beaver (1966), şirketlerin iflas ve finansal başarısızlığa düşme riskini incelemek amacıyla tek değişkenli finansal başarısızlık modellerini kullanmış ve Beaver modelini geliştirmiştir. Altman (1968), 1946-1965 yılları arasında 33 adet finansal başarısızlık yaşayan işletme ile yine 33 adet başarılı işletmeyi incelemiş ve işletmeleri iflas edip etmemesine göre iki gruba ayırarak işletmelerin finansal oranlarının, bu grupları ayırt edebilecek doğrusal modellerini araştırmıştır. Çalışma sonucunda Altman Z Skor modeli geliştirilmiştir. Weibel (1973), İsviçre'de bulunan büyük bir bankanın müşterileri olan küçük ölçekli işletmeler üzerinde analiz gerçekleştirmiş ve Weibel modelini geliştirmiştir. Springate (1978), Kanada'daki imalat firmaları üzerinde gerçekleştirdiği araştırma sonucunda çok değişkenli ayırma (diskriminant) analizini kullanarak Springate modelini geliştirmiştir. Ohlson (1980), çalışmasında işletmelerin başarısızlıklarını önceden tahmin etmek için çoklu ayırma analizi yöntemini kullanmış ve O-skor modelini geliştirmiştir. Fulmer (1984), çok değişkenli ayırma analizini kullandığı araştırmasında işletmelerin finansal başarısızlık riskini tahmin etmede Fulmer modelini geliştirmiştir. Legault (1987) ise imalat işletmeleri üzerinde gerçekleştirdiği çalışma neticesinde Kanada Skoru (CA-Score) modelini geliştirmiştir.

Konuyla ilgili literatür taraması neticesinde, yukarıda ifade edilen finansal başarısızlık riski tahmin modellerini geliştiren araştırmalardan sonra farklı sektörlere yönelik olarak bu modelleri kullanarak işletmelerin finansal başarısızlık risklerini belirlemeye yönelik çalışmalarında oldukça fazla gerçekleştirildiği görülmektedir.

Huo (2006), Altman modelinin Amerika Birleşik Devletleri'nde bulunan restoranların finansal başarısızlıklarını önceden tahmin etmede en başarılı model olduğu sonucuna ulaşmıştır. Poyraz ve Uçma (2006), gıda, tekstil, tarımsal ürün, ulaştırma ve turizm sektörlerinin yaşanan 1994 ve 2001 krizlerindeki finansal başarısızlıklarını Altman Z modeline göre ölçmüşler ve turizm sektörü özelinde finansal krizlerin, turizm işletmelerinin finansal başarısızlık risklerini çok fazla etkilemediğini belirlemişlerdir. Muzır ve Çağlar (2009), çalışmalarında Türkiye'de faaliyet gösteren işletmelerin finansal başarısızlıklarının tahmininde O-Skor modelinin \% 81,6 doğru sınıflandırma oranıyla başarılı olduğunu saptamışlardır. Diakomihalis (2012), Altman Z modellerinin Yunanistan'da faaliyet gösteren konaklama işletmelerinin iflas risklerini bir yıl öncesinden tahmin edilmesinde \%88,24 başarılı olduğunu saptamıştır. İskenderoğlu ve Karakozak (2013), 2008 yılında yaşanan küresel finansal krizinin BíST imalat işletmelerinin finansal başarısızlık riskleri üzerindeki etkisini Altman Z Skor modeliyle ölçmüşler ve 2008 yılının ilk çeyreğinden 2009 yılı son çeyreğine kadar finansal başarısızlık risklerinde artış olduğunu gözlemlemiş̧lerdir. Büyükarıkan ve Büyükarıkan (2014), BIST'de işlem gören bilişim işletmelerinin finansal başarısızlıklarını ölçmek için 
Altman Z Skoru ve Springate modellerini kullanmışlar ve her iki modele göre işletmelerin finansal başarısızlık riski taşımadığı sonucuna ulaşmışlardır. Karadeniz, Koşan ve Kahiloğulları (2014), BiST'de işlem gören 4 spor işletmesinin Altman Z değerlerini hesaplayarak 2 spor işletmesinin finansal başarısızlık riski taşıdığını belirlemişlerdir. Türk ve Kürklü (2017), çalışmalarında BIST 100 endeksinde yer alan birbirinden farklı 7 sektörün finansal başarısızlıklarını Altman Z Skor ve Springate modelleriyle ölçmüşler ve bu iki modele göre sektörlerin finansal başarısızlık risklerinin farklı olduğunu belirlemişlerdir. Jawabreh, Rawashdeh ve Senjelawi (2017), Ürdün'de faaliyet gösteren konaklama işletmelerinin finansal başarısızlıklarını önceden tahmin etmek için Altman Z Skorunu kullanmışlar ve işletmelerin finansal başarısızlıklarının bir yıl önceden kendisini gösterdiği sonucuna ulaşmışlardır.

Konuyla ilgili yine gerçekleştirilen literatür taramasında finansal başarısızlık riski taşıyan işletmelerle finansal başarısızlık riski taşımayan işletmelerin finansal oranları veya finansal performansları arasında ne gibi farklılıkların olduğunu belirlemeye yönelik araştırmaların ise kısıtlı sayıda olduğu belirlenmiştir.

DeAngelo ve DeAngelo (1990), New York Borsası'na kote olan ve finansal sıkıntı yaşayan işletmelerin daha az kar payı dağıtma yoluna gittiklerini saptamışlardır. Hill, Perry ve Andes (1996), NYSE ve AMEX'te işlem gören 257 adet imalat ve perakende işletmesi içinde finansal açıdan başarısız olanların likidite ve karlılık oranlarının daha düşük olduğu buna karşın kaldıraç oranlarının daha yüksek olduğunu saptamışlardır. Altaş ve Giray (2005), tekstil işletmelerinde finansal başarısızlıkla likidite oranları arasında anlamlı bir ilişki olduğunu saptamışlardır. İçerli ve Akkaya (2006), o tarihteki adıyla İstanbul Menkul Kıymetler Borsası'na 1990-2003 yılları arasında kote olan 40 adet finansal olarak başarılı ve yine 40 adet başarısız imalat işletmesinin cari oran, asit-test oranı, alacak devir hızı ve kaldıraç oranları arasında istatistiksel olarak anlamlı bir farklılık olduğunu saptamışlardır. Buna karşın araştırmada aktif ve stok devir hızı ile karlılık oranları bakımından önemli farklılıklar bulunmadığı belirlenmiştir. Selimoğlu ve Orhan (2015), BIST'de işlem gören 25 adet dokuma, giyim eşyası ve deri işletmesi üzerinde finansal açıdan başarılı ve başarısız olan işletmeler arasında duran varlıklar/özkaynaklar, faiz karşılama oranı, faaliyet kâr marjı, net kâr marjı, özkaynak kârlılığı, aktif kârlıı̆ı ve FVÖK/aktif toplamı oranları bağlamında istatistiksel olarak anlamlı bir farklılık olduğunu belirlemişlerdir. Akyüz, Yıldırım, Akyüz ve Tugay (2017), BiST'de işlem gören 13 adet kâğıt ve kâğıt ürünleri sanayi işletmesi içinde finansal açıdan başarılı ve başarısız olan işletmeler arasında istatistiksel olarak anlamlı farklılık taşıyan oranların sadece karlılık ile ilgili oranlar olduğu sonucuna ulaşmışlardır.

Yukarıda özetlenmeye çalışılan araştırmalar bağlamında turizm sektörüne yönelik gerçekleştirilen araştırmaların kısıtlı olduğu görülmektedir. Özellikle turizm sektöründe finansal başarısızlık riski içerisinde olan ve olmayan turizm işletmelerinin finansal oranları arasında farklııı olup olmadığına ilişkin daha önce gerçekleştirilen bir araştırmaya tarafımızca ulaşılamamıştır. Bu bağlamda araştırmanın literatüre katkı sağlayacağı düşünülmektedir.

\section{Yöntem}

Araştırmanın amaçları doğrultusunda öncelikle BIST'de 2012-2017 yılları arasında işlem gören ve finansal verilerine ulaşılan 11 adet turizm işletmesinin finansal başarısızlık risk düzeyleri Altman Z Skor Modeliyle belirlenmiştir. BiST'de faaliyet gösteren 12 tane turizm işletmesi bulunmaktadır. Bunlardan bir tanesinin finansal durum tablolarında analiz için gerekli olan 2012-2017 dönemi verileri eksik olduğundan 
analize 11 turizm işletmesi dâhil edilmiştir. Söz konusu turizm işletmeleri ağırlıklı olarak konaklama faaliyetleri olmak üzere yiyecek-içecek işletmeciliği, ulaştırma, turizm yatırımı, inşaat, taahhüt ve kiralama gibi alanlarda faaliyet göstermektedirler. Analize dahil turizm işletmelerinin isimleri aşağıdaki tabloda sunulmaktadır.

\section{Tablo 1: Analiz Kapsamındaki BisT Turizm İşletmeleri}

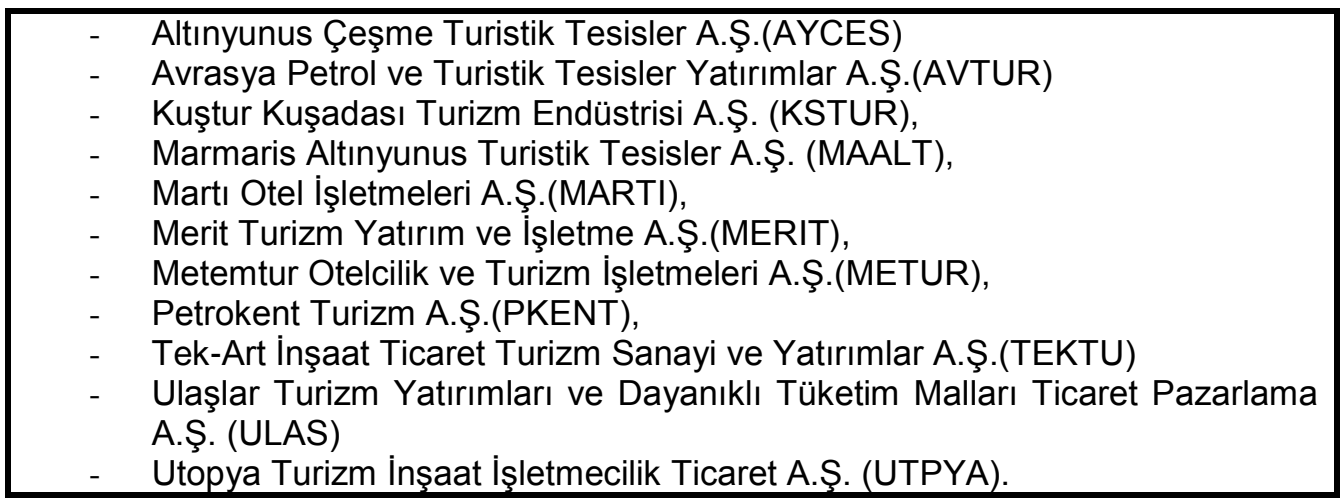

Tablo 1'de sunulan turizm işletmeleri sermaye piyasasında işlem gören halka açık işletmeler olduklarından dolayı, araştırmanın ilerleyen kısımlarında Sermaye Piyasası Kanunu uyarınca herhangi bir finansal spekülasyona neden olmamak için harflerle kodlanarak sunulmaktadır. Söz konusu işletmelerin hesaplamalarda kullanılan finansal verilerine Kamuyu Aydınlatma Platformu internet adresinden (www.kap.gov.tr) ve Thomson Reuters Eikon Veri Tabanından ulaşılmıştır.

Analize dahil turizm işletmelerinin 2012-2017 yılları arasındaki finansal başarısızlık riskleri finans literatüründe en fazla kabul gören Altman Z Skor Modeliyle hesaplanmıştır. Altman Z Skor modeli, Edward I. Altman tarafından iflasları analiz etmek ve önceden tahmin edebilmek için 1968 yılında geliştirilmiştir. Altman (1968), daha önce finansal başarısızlığı ölçmek için yapılan çalışmalarda kullanılan oranların analiziyle bulunan sonuçları teorik ve pratik olarak şüpheli bulduğu için çalışmasında kendisinin geliştirdiği ilk çoklu doğrusal ayrışma tabanlı Z Skoru modelini kullanmıştır. Çalışmada, tesadüfi örnekleme yöntemi kullanılarak, imalat sektöründen 33 başarılı ve 33 başarısız işletme seçilmiş ve 22 adet finansal oran içinden belirlenen 5 oran, işletmelerin finansal başarısızlığını ölçmede kullanılmıştır. 2013);

Modelde kullanılan oranlar ve denklem aşağıdaki gibidir (Aksoy ve Yalçıner,

Z Skoru $=\left(0,012 X_{1}\right)+\left(0,014 X_{2}\right)+\left(0,033 X_{3}\right)+\left(0,006 X_{4}\right)+\left(0,999 X_{5}\right)$

Modelde;

$\mathrm{X}_{1}=$ Net İşletme Sermayesi / Toplam Varlıklar

$\mathrm{X}_{2}=$ Dağıtılmamış Karlar / Toplam Varlıklar

$\mathrm{X}_{3}=$ Faiz ve Vergi Öncesi Kar / Toplam Varlıklar

$\mathrm{X}_{4}=$ Öz Sermaye (Cari Değer) / Toplam Borç

$\mathrm{X}_{5}=$ Satışlar / Toplam Varlıklar'dır. 
Bu modeli oluşturan beş orana bakıldığında (Özdemir, 2014);

I. Net İşletme Sermayesi / Toplam Varlıklar: Bu oran işletmenin likidite durumunu göstermektedir.

II. Dağıtılmamış Karlar / Toplam Varlıklar: Bu oran işletmenin oto finansman kapasitesini göstermektedir.

III. Faiz ve Vergi Öncesi Kar / Toplam Varlıklar: İşletmenin faaliyet karlılığını göstermektedir.

IV. Öz Sermaye / Toplam Borç: İşletmenin finansal yapısını veya kaldıraç gücünü göstermektedir.

V. Satışlar / Toplam Varlıklar: İşletmenin toplam varlıklarına göre gerçekleştirdiği satışlarını göstermektedir. Diğer bir ifadeyle varlıkların kullanım kapasitesini göstermektedir.

İşletmeye ait $X$ değerlerinin elde edilmesiyle $X_{1}, X_{2}, X_{3}$ ve $X_{4}$ değerleri 100 ile çarpılır, $X_{5}$ değeri ise olduğu gibi hesaplamaya katılmaktadır. Elde edilen $X$ değerleri, modelde her biri ayrı katsayılarla çarpılıp toplandığında $Z$ değerine ulaşılmaktadır. Altman'ın oluşturduğu model doğrultusunda bulunan $Z$ değeri 1,81'den küçükse gelecek yıllar için işletmenin finansal başarısızlık riskinin yüksek olduğu kabul edilmektedir. $Z$ değeri 1,81-2,99 arasında bir değere sahip ise işletme için tam bir fikre sahip olunamaz. Z değeri 2,99'dan büyük ise işletmenin iyi bir finansal yapıya sahip olduğu ve gelecek birkaç yıl içinde finansal başarısızlık riskini taşımadığı kabul edilmektedir (Aksoy ve Yalçıner, 2013). Analize dâhil turizm işletmelerinin 2012-2017 yılları arasındaki finansal başarısızlık risklerinin Altman $Z$ Skor modeliyle hesaplanmasıyla, analiz sürecinde 29 adet finansal başarısızlık riski taşıyan ve 29 adet finansal başarısızlık riski taşımayan işletme olduğu belirlenmiştir.

Tablo 2: Çalışmada Hesaplanan Finansal Oranlar

\begin{tabular}{|c|c|c|}
\hline Finansal Oran Adı & Hesaplanma Şekli & Hesaplanma Amacı \\
\hline Cari Oran & $\begin{array}{l}\text { Dönen Varlıklar / Kısa Vadeli } \\
\text { Yabancı Kaynaklar }\end{array}$ & $\begin{array}{lrr}\text { İşletmenin } & \text { k1sa } & \text { vadeli } \\
\text { yükümlülüklerini } & \text { karşılama } \\
\text { kapasitesini ve } & \text { likidite } \\
\text { durumunu ölçmek. } & \\
\end{array}$ \\
\hline Asit-Test Oran1 & $\begin{array}{l}\text { (Dönen Varlıklar - Stoklar) / } \\
\text { Kısa Vadeli Yabancı Kaynaklar }\end{array}$ & $\begin{array}{l}\text { İşletmenin stoklarını satışlara } \\
\text { dönüştürememesi durumunda } \\
\text { kısa vadeli yükümlülüklerini } \\
\text { karşılama kapasitesini ölçmek. }\end{array}$ \\
\hline Nakit Oran & $\begin{array}{l}\text { Hazır Değerler + Menkul } \\
\text { Kiymetler / Kısa Vadeli Yabancı } \\
\text { Kaynaklar }\end{array}$ & $\begin{array}{l}\text { İşletmenin hazır değerleriyle } \\
\text { kısa vadeli yükümlülüklerini } \\
\text { karşılama kapasitesini ölçmek. }\end{array}$ \\
\hline Kaldıraç Oranı & $\begin{array}{l}\text { Yabancı Kaynaklar / Aktif } \\
\text { (Kaynak)Toplamı }\end{array}$ & $\begin{array}{l}\text { İşletmenin } \\
\text { finansmanındıklarının } \\
\text { kullanım düzeyini ölçmek. }\end{array}$ \\
\hline $\begin{array}{l}\text { Kısa Vadeli Kaldıraç } \\
\text { Oranı }\end{array}$ & $\begin{array}{l}\text { Kisa Vadeli Yabancı Kaynaklar / } \\
\text { Toplam Kaynaklar }\end{array}$ & $\begin{array}{l}\text { İ̀şletmenin k1sa vadeli } \\
\text { borçlardan yararlanma düzeyini } \\
\text { ölçmek. }\end{array}$ \\
\hline Alacak Devir Hızı & Net Satışlar / Ticari Alacaklar & $\begin{array}{l}\text { İ́letmenin alacak tahsilat } \\
\text { politikasının etkinliğini ölçmek. }\end{array}$ \\
\hline
\end{tabular}


Tablo 2'nin devamı

\begin{tabular}{|l|l|l|}
\hline Stok Devir Hızı & Satışların Maliyeti / Stok Miktarı & $\begin{array}{l}\text { İşletmenin stok yönetim } \\
\text { politikasının etkinliğini ölçmek }\end{array}$ \\
\hline Aktif Devir Hızı & Net Satışlar / Aktif Toplamı & $\begin{array}{l}\text { İşletmenin, toplam aktif } \\
\text { yönetim politikasının } \\
\text { etkinliğini ölçmek. }\end{array}$ \\
\hline Aktif Karlılık Oranı & Net Kar / Aktif Toplamı & $\begin{array}{l}\text { İşletmenin, aktiflerini ne ölçüde } \\
\text { karlı kullandığını ölçmek. }\end{array}$ \\
\hline $\begin{array}{l}\text { Öz Sermaye Karlılık } \\
\text { Oranı }\end{array}$ & Net Kar / Öz Sermaye Toplamı & $\begin{array}{l}\text { İşletmenin ortaklarına sunduğu } \\
\text { karlılığı ölçmek. }\end{array}$ \\
\hline Net Kar Marjı & Net Kar / Net Satışlar & $\begin{array}{l}\text { I̧şletmenin satışları üzerinden } \\
\text { sağladığı karlılığı ölçmek. }\end{array}$ \\
\hline $\begin{array}{l}\text { Satışların Maliyetinin Net } \\
\text { Satışlara Oranı }\end{array}$ & Satış Maliyeti / Net Satışlar & $\begin{array}{l}\text { Isşletmenin satış maliyetlerinin } \\
\text { net satışları içerisindeki payını } \\
\text { ölçmek. }\end{array}$ \\
\hline Fiyat Kazanç Oranı & $\begin{array}{l}\text { Hisse Senedi Fiyatı / Hisse } \\
\text { Başına Düşen Kazanç }\end{array}$ & $\begin{array}{l}\text { Yatırımcıların, işletmenin hisse } \\
\text { başına karına karşılık hisse } \\
\text { senedine ne kadar ödemek } \\
\text { istediklerini saptamak. }\end{array}$ \\
\hline
\end{tabular}

Kaynak: (Andrew ve Schmidgall, 1993; Brealy ve diğ., 1995; White ve diğ., 1997; Jagels ve Coltman, 2004; Karadeniz ve diğ., 2016).

Daha sonra finansal başarısızlık riski içerisinde olan ve olmayan turizm işletmeleri açısından likidite, mali yapı, faaliyet, karlılık ve piyasa performansını ölçen 13 adet önemli finansal oran ayrı ayrı hesaplanmış ve iki grup arasında finansal oranlar bağlamında istatistiksel olarak anlamlı bir farklılık olup olmadığı belirlenmeye çalışılmıştır. Söz konusu finansal oranlar Tablo 2'de sunulmaktadır.

İki bağımsız grup arasındaki farklılıkların analizinde, parametrik testlerden iki grubun ortalamalarının karşılaştırıldığı t-testi uygulanmaktadır. Bu bağlamda öncelikle verilerin normal dağılıma sahip olup olmadıklarını saptamak için küçük gruplar için önerilen Shapiro-Wilk normallik testi uygulanmış ve test sonucunda $p$ değerleri 0,05'den küçük çıkmıştır. Dolayısıyla normal dağılıma sahip olmadığı saptanan veriler, t-testinin parametrik olmayan alternatifi olan Mann-Whitney $U$ testine tabi tutulmuştur. Mann-Whitney U testi, normal dağılım özelliği göstermeyen bir dağılımda iki bağımsız grup ortalamalarını karşılaştırmak amacıyla kullanılan parametrik olmayan bir yöntemdir. (Kalaycı, 2014). Verilerin analizinde anlamlılık düzeyi 0,05 olarak kabul edilmiştir.

\section{Bulgular}

Analiz kapsamında öncelikle BIST turizm işletmelerinin 2012-2017 yılları arasındaki Altman Z Skor değerleri ve bu değerlere göre finansal başarısızlık riski taşıma, finansal başarısızılık riski taşımama ve finansal başarısızlık riskleri hakkında yorum yapılamama durumları belirlenmiştir. Tablo 3'de analiz kapsamındaki turizm işletmelerinin Altman Z Skor değerleri verilmektedir. Tabloda finansal başarısızlık riski içerisinde olmayan işletmeler mavi, finansal başarısızlık riski içerisinde olan işletmeler kırmızı, finansal başarısızlık riskleri hakkında yorum yapılamayan işletmelere ait veriler ise gri olarak vurgulanmıştır. İşletme isimleri ise kodlanarak verilmiştir. 
Tablo 3'te analize dâhil edilen işletmelerin finansal başarısızlık riskleri incelendiğinde, Altman Z Skor modeline göre altı yıllık analiz sürecinde toplam 29 adet finansal başarısızlık riski göstermeyen işletme, yine 29 adet finansal başarısızlık riski gösteren işletme ve 8 adet gri bölgede yer alan işletmenin olduğu görülmektedir. 20122017 yılları arasında 3 turizm işletmesinin (C, D ve F işletmesi) hiçbir yıl finansal başarısızlık riski taşımadığı ve başarılı olduğu, buna karşın yine 3 turizm işletmesinin ise $(E, H$ ve $K$ işletmesi) her yıl finansal başarısızlık riski içerisinde olduğu görülmektedir. 5 turizm işletmesinin ( $A, B, G$, I ve $J$ işletmeleri) ise analiz sürecinde finansal başarısızlık risklerinin değişkenlik gösterdiği saptanmıştır.

Tablo 3: BiST Turizm İşletmelerinin 2012-2017 Yılları Arasındaki Altman Z Skor Değerleri

\begin{tabular}{|l|l|l|l|l|l|l|}
\hline & $\mathbf{2 0 1 2}$ & $\mathbf{2 0 1 3}$ & $\mathbf{2 0 1 4}$ & $\mathbf{2 0 1 5}$ & $\mathbf{2 0 1 6}$ & $\mathbf{2 0 1 7}$ \\
\hline A işletmesi & 2,89 & 2,69 & 2,83 & 3,37 & 2,14 & 1,86 \\
\hline B işletmesi & 7,8 & 6,01 & 7,62 & 4,93 & 3,15 & 2,06 \\
\hline C işletmesi & 10,1 & 7,3 & 5,07 & 4,01 & 12,46 & 9,98 \\
\hline D işletmesi & 5,5 & 24 & 27,6 & 14,7 & 4,6 & 3,87 \\
\hline E işletmesi & 0,23 & $-0,06$ & $-0,09$ & $-0,06$ & $-0,5$ & $-0,73$ \\
\hline F işletmesi & 8,2 & 6,77 & 7,46 & 8,47 & 8,68 & 6,27 \\
\hline G işletmesi & 0,55 & $-0,89$ & $-1,38$ & 3,55 & 9,45 & 0,49 \\
\hline H işletmesi & 0,33 & 1,69 & 0,07 & 0,76 & $-1,5$ & 0,99 \\
\hline I işletmesi & 5,73 & 4,39 & 2,01 & 1,16 & 0,42 & 0,96 \\
\hline $\mathrm{J}$ işletmesi & 3,72 & 0,81 & 0,49 & $-0,13$ & $-0,8$ & 1,95 \\
\hline K işletmesi & 0,93 & 0,22 & 0,86 & 0,89 & $-0,36$ & $-0,13$ \\
\hline
\end{tabular}

Tablo 4'te ise 2012-2017 yılları arasında finansal başarısızlık riski içerisinde olan işletmelerle, finansal başarısızlık riski içerisinde olmayan işletmelere ait hesaplanan 13 adet finansal oranın ortalama değerleri ve analiz sürecinde finansal oranlar bağlamında farklıık olup olmadığına dair gerçekleştirilen Mann-Whitney $U$ testine ait sonuçlar yer almaktadır. Tablo 4'e göre finansal başarısızlık riski taşıyan ve taşımayan turizm işletmeleri arasında; cari oran, asit-test oranı, nakit oran, kaldıraç oranı, kısa vadeli kaldıraç oranı, aktif karlılık oranı, öz sermaye karlılık oranı, net kar marjı ve fiyat kazanç oranları bağlamında istatistiksel olarak anlamlı bir farklılık olduğu görülmektedir. Buna karşın alacak devir hızı, stok devir hızı, aktif devir hızı ve satışların maliyetinin net satışlara oranı bağlamında iki grup arasında istatistiksel olarak anlamlı bir fark olmadığı saptanmıştır.

Oranların ortalamaları incelendiğinde finansal başarısızlık riski içerisinde olan işletmelerin cari oran, asit-test oranı ve nakit oran ortalamalarının düşük düzeylerde gerçekleştiği buna karşın finansal başarısızlık riski içerisinde olmayan işletmelerin ise cari oran, asit-test oranı ve nakit oran ortalamalarının yüksek düzeylerde gerçekleştiği görülmektedir. 
Tablo 4: Finansal Başarısızlık Riski Taşıyan İşletmelerle, Finansal Başarısızlık Riski Taşımayan İşletmelerin Finansal Oranları Arasındaki Farklılık Analizi Sonuçları

\begin{tabular}{|l|c|c|c|c|c|}
\hline & $\begin{array}{l}\text { Başarısız } \\
\text { İşletme } \\
\text { Ortalaması } \\
(\mathbf{n = 2 9 )}\end{array}$ & $\begin{array}{l}\text { Başarılı } \\
\text { İşletme } \\
\text { Ortalaması } \\
(\mathbf{n = 2 9 )}\end{array}$ & $\begin{array}{l}\text { Mann- } \\
\text { Whitney U } \\
\text { Değeri }\end{array}$ & Z Değeri & $\begin{array}{l}\text { p } \\
\text { Değeri }\end{array}$ \\
\hline Oranlar & 1,08 & 5,10 & 115 & $-4,74$ & $0,000^{*}$ \\
\hline Cari Oran & 0,75 & 4,58 & 80 & 5,29 & $0,000^{*}$ \\
\hline Asit-Test Oranı & 0,19 & 3,12 & 220,5 & $-3,10$ & $0,002^{*}$ \\
\hline Nakit Oran & 0,66 & 0,13 & 26 & 6,13 & $0,002^{*}$ \\
\hline Kaldıraç Oranı & 0,32 & 0,07 & 23 & 6,17 & $0,000^{*}$ \\
\hline Kısa Vadeli Kaldıraç Oranı & 42,67 & 33,38 & 347 & $-1,14$ & 0,254 \\
\hline Alacak Devir Hızı & 22,53 & 75,00 & 363,5 & $-0,87$ & 0,378 \\
\hline Stok Devir Hızı & 0,25 & 0,32 & 396,5 & $-0,37$ & 0,711 \\
\hline Aktif Devir Hızı & $-0,06$ & 0,09 & 102,5 & $-4,94$ & $0,000^{*}$ \\
\hline Aktif Karlılık Oranı & $-0,33$ & 0,15 & 112 & $-4,79$ & $0,000^{*}$ \\
\hline Öz Sermaye Karlıık Oranı & $-0,65$ & 0,74 & 138 & $-4,39$ & $0,000^{*}$ \\
\hline Net Kar Marjı & 0,76 & 0,78 & 315 & 1,63 & 0,103 \\
\hline $\begin{array}{l}\text { Satışların Maliyetinin Net } \\
\text { Satışlara Oranı }\end{array}$ & 0,14 & 5,65 & 193 & $-3,53$ & $0,000^{*}$ \\
\hline Fiyat Kazanç Oranı & & & & & \\
\hline
\end{tabular}

${ }^{*} 0,05$ düzeyinde anlamlıdır.

Kaldıraç oranı ve kısa vadeli kaldıraç oranları açısından ise finansal başarısızlık riski içerisinde olan işletmelerin daha yüksek değerlere sahip oldukları söylenebilir. Alacak devir hızı açısından ise finansal başarısızlık riski içerisinde olan işletmelerin ortalamasının buna karşın stok devir hızı açısından ise finansal başarısızlık riski içerisinde olmayan işletmelerin ortalamalarının daha yüksek gerçekleştiği saptanmıştır. Aktif devir hızı açısından ise iki grubun değerlerinin birbirine daha yakın olduğu ve finansal başarısızlık riski içerisinde olmayan işletmelerin biraz daha yüksek ortalamaya sahip olduğu belirlenmiştir. Karlılık oranlarının (aktif karlıığı, özsermaye karlılığı ve net kar marjı) ortalamaları her iki grup açısından incelendiğinde ise finansal başarısızlık riski içerisinde olan işletmelerin ortalamalarının negatif gerçekleştiği, finansal başarısızlık riski içerisinde olmayan işletmelerin ortalamalarının ise pozitif gerçekleştiği görülmektedir. Satışların maliyetinin net satışlara oran ortalamasının ise her iki grupta birbirine çok yakın olduğu söylenebilir. Fiyat / Kazanç oran ortalamasının ise finansal başarısızlık riski içerisinde olmayan işletmeler açısından çok daha yüksek gerçekleştiği ifade edilebilir.

\section{Sonuç ve Öneriler}

Son yıllarda dünya ekonomisinde yaşanan küreselleşmeyle sürekli ağırlaşan rekabet, uluslararası ticarette uygulanan korumacılık politikaları, ticaret ve kur savaşlarıyla birlikte gün geçtikçe zorlaşan ekonomik şartlar, işletmelerin varlıklarını sürdürebilmelerini ve amaçlarını gerçekleştirebilmelerini zorlaştırmaktadır. Ülkelerde yaşanan ekonomik sorunlar ve işletmelerin kontrolü dışındaki etmenlerden kaynaklı 
problemler, ülkelerin gelişmişlik düzeyini gözetmeksizin devletlerin ve işletmelerin finansal başarısızlıkla karşılaşabilmesine hatta iflas sürecini yaşamasına neden olabilmektedir. Türkiye'de de son dönemde özellikle dışsal etkenlerden dolayı döviz kurlarında meydana gelen dalgalanmalar, bir yandan işletmelerin ithalata bağımlı olarak gerçekleştirdikleri üretimin maliyetlerini arttırmakta diğer yandan hane halkı gelir seviyesini düşürmekte ve sonuçta talep tarafında daralmalar meydana gelmektedir. Bununla birlikte 2018 yılında 240 milyar doları bulan özel sektör dış borcunun geri ödemesinde hem dolar kurundaki dalgalanmalar hem de üretim maliyetlerindeki artış ve talep daralması nedeniyle işletmeler büyük zorluklar yaşamaktadır.

Finansal bağlamda işletmelerin bu ağır ve değişken ekonomik şartlar altında faaliyetlerini devam ettirebilmeleri için yatırım ve faaliyet dönemindeki maliyetlerini kontrol edebilmeleri, finansman maliyetlerini azaltmaları, doğru bir varlık ve kaynak yönetimine odaklanmaları gerekmektedir. Özellikle turizm işletmelerinin, kontrolleri dışında olan sistematik risklere karşı hassas olması ayrıca yüksek düzeyde sabit sermaye yatırımları gerçekleştirmeleri nedeniyle faaliyet ve finansal risklerini ölçmeleri ve yönetmeleri önem arz etmektedir.

Bu araştırmada finansal başarısızlık riski taşıyan ve taşımayan turizm işletmeleri arasında likidite, mali yapı, faaliyet, karlılık ve piyasa performansı bağlamında bir karşılaştırma yapmak ve istatistiksel açıdan anlamlı bir farklılık olup olmadığını belirlemek amaçlanmıştır. Belirlenen amaç doğrultusunda BIST'de işlem gören 11 turizm işletmesinin 2012-2017 yılları arasındaki finansal verileri üzerinden öncelikle finansal başarısızlık riskleri Altman Z Skor modeli kullanılarak belirlenmiştir. Bu bağlamda 11 turizm işletmesi üzerinde ve 6 yıllık analiz süreci içerisinde 66 gözlem gerçekleştirilmiş ve yapılan hesaplama sonucunda 29 adet finansal başarısızlık riski göstermeyen işletme, yine 29 adet finansal başarısızlık riski gösteren işletme ve 8 adet gri bölgede yer alan işletmenin olduğu tespit edilmiştir. Analize dahil işletmelerin finansal başarısızlık risklerine göre ayrışması yapıldıktan sonra, bu işletmelerin likidite, mali yapı, faaliyet, karlılık ve piyasa performansını ölçen 13 adet önemli finansal oranı hesaplanmış ve bu oranlar açısından istatistiksel açıdan anlamlı bir farklılığın var olup olmadığı analiz edilmiştir.

Likidite performansını belirleyebilmek için yapılan hesaplamalar neticesinde finansal başarısızlık riski taşıyan turizm işletmelerinin likidite oranlarının çok daha düşük gerçekleştiği belirlenmiş ve likidite oranlarında her iki grup işletme açısından istatistiksel olarak anlamlı farklılıklar saptanmıştır. Dolayısıyla likidite oranları incelendiğinde, finansal başarısızlık riski taşıyan turizm işletmelerinin vadesi gelen yükümlülüklerini yerine getirmede oldukça zorlandıklarını söylemek mümkündür. $\mathrm{Bu}$ bulgu finans teorisinde bulunan finansal başarısızlık kavramının tanımıyla uyum göstermektedir (Brigham ve Ehrhardt, 2010). Ayrıca elde edilen bu bulgu konuyla ilgili daha önce gerçekleştirilen araştırma sonuçlarıyla da paralellik göstermektedir (Hill, Perry ve Andes, 1996; Altaş ve Giray, 2005; i̇çerli ve Akkaya, 2006).

Mali yapı performansını her iki grup açısından belirleyebilmek için kaldıraç oranı ve kısa vadeli kaldıraç oranları hesaplanmış ve bu oranlar açısından istatistiksel olarak anlamlı bir farklılığın olup olmadığı test edilmiştir. Yapılan hesaplamalar neticesinde finansal başarısızlık riski taşıyan turizm işletmelerinin kaldıraç oranlarının çok daha yüksek olduğu belirlenmiş ve kaldıraç oranlarında her iki grup işletme açısından istatistiksel olarak anlamlı farklılıklar saptanmıştır. Diğer bir ifadeyle finansal başarısızlık riski taşıyan turizm işletmelerinin finansmanda çok daha fazla yabancı kaynak ve kısa vadeli yabancı kaynak kullandığını ve bu durumun işletmelerin finansal riskini arttırdığını söylemek mümkündür. Elde edilen bu bulgu konuyla ilgili daha önce 
gerçekleştirilen araştırma sonuçlarıyla da paralellik göstermektedir (Hill, Perry ve Andes, 1996; İçerli ve Akkaya, 2006; Selimoğlu ve Orhan, 2015).

İşletme faaliyetlerinde kullanılan varlıkların ne kadar etkin kullanıldığını ölçen faaliyet oranlarının hesaplanması neticesinde; alacak devir hızı bağlamında finansal başarısızlık riski içerisinde olan turizm işletmelerinin ortalamasının daha yüksek gerçekleştiği ancak finansal başarısızlık riski içerisinde olmayan turizm işletmelerinin ortalamasıyla istatistiksel olarak anlamlı bir fark olmadığı belirlenmiştir. Dolayısıyla alacak tahsilât etkinliği açısından finansal başarısızlık riski içindeki turizm işletmelerinin çok büyük fark da olmasa daha başarılı olduğunu söylemek mümkündür. Ancak bu farklılık, istatistiksel olarak önemli düzeyde değildir. Bu bulgu, başarısız işletmelerin alacak devir hızı ortalamasının daha yüksek olması açısından İçerli ve Akkaya (2006) çalışmasıyla paralellik göstermekte ancak istatistiksel olarak anlamlı farklılığın çıkmaması bağlamında yine İçerli ve Akkaya (2006) çalışmasıyla paralellik göstermemektedir. Bu farklılığın ise örneklem bağlamında analize dahil edilen işletmelerin alacak devir hızları ortalamalarının birbirine yakın olmasından kaynaklandığı düşünülmektedir.

Stok devir hızı bağlamında finansal başarısızlık riski içerisinde olmayan başarılı turizm işletmelerinin ortalamasının çok daha yüksek gerçekleştiği ancak finansal başarısızlık riski içerisinde olan turizm işletmelerinin ortalamasıyla istatistiksel olarak anlamlı bir fark olmadığı belirlenmiştir. Bu bağlamda stokların satışa dönüşme kabiliyeti açısından finansal başarısızlık riski içinde olmayan turizm işletmelerinin daha başarılı olduğunu söylemek mümkündür ancak bu farklılık istatistiksel olarak önemli düzeyde değildir. Elde edilen söz konusu bulgu İçerli ve Akkaya (2006) çalışmasıyla paralellik göstermektedir. Aktif devir hızı bağlamında da her iki grubun ortalamalarının birbirine yakın ve düşük gerçekleştiği saptanmış dolayısıyla her iki grup açısından istatistiksel bir farklılık olmadığı tespit edilmiştir. Her iki grubun ortalamalarının düşük ve birbirine yakın çıkması doğrultusunda turizm işletmelerinin aktif büyüklüklerinin çok büyük olması ve aktiflerini etkin kullanma bağlamında başarılı ve başarısız işletmelerin düşük performans gerçekleştirdiklerini söylemek mümkündür. Elde edilen bu bulgu İçerli ve Akkaya (2006) çalışmasıyla paralellik göstermektedir.

Her iki grup açısından karlılık performansını belirleyebilmek için gerçekleştirilen hesaplamalar neticesinde finansal başarısızlık riski taşıyan turizm işletmelerinin aktif karlılık oranı, öz sermaye karlılık oranı ve net kar marjlarının negatif gerçekleştiği buna karşın finansal başarısızlık riski taşımayan turizm işletmelerinin söz konusu karlılık oranlarının pozitif ortalamaya sahip olduğu saptanmıştır. Ayrıca karlılık performansı bağlamında her iki grup arasında istatistiksel olarak anlamlı bir farklılık olduğu belirlenmiştir. Elde edilen bu sonuç; Hill, Perry ve Andes (1996), Selimoğlu ve Orhan (2015), Akyüz, Yıldırım, Akyüz ve Tugay (2017) çalışma sonuçlarıyla paralellik göstermektedir. Satışların maliyetinin net satışlara oranının ise her iki grupta birbirine yakın ve yüksek çıktığı saptanmış ve aralarında istatistiksel olarak anlamlı bir farklılık olmadığı belirlenmiştir.

Piyasadaki yatırımcıların işletmeden beklentilerinin bir göstergesi olarak kullanılan fiyat/kazanç oranı açısından her iki grubu değerlendirmek için gerçekleştirilen hesaplamalar neticesinde finansal başarısızlık riski göstermeyen turizm işletmelerinin fiyat/kazanç oranı ortalaması 5,65 olarak belirlenmiştir. Buna karşın finansal başarısızlık riski gösteren turizm işletmelerinde ise oranın ortalaması 0,14 olarak belirlenmiş ve her iki grup arasında istatistiksel olarak anlamlı bir farklılığın olduğu saptanmıştır. Genel anlamda fiyat/kazanç oranı, bir işletmenin hisse başına sunacağı her 1 TL'lik kar için yatırımcıların ne kadar ödemeye istekli olduğunu 
göstermektedir. Dolayısıyla elde edilen bu bulguyla yatırımcıların, finansal başarısızlık riski göstermeyen turizm işletmelerinde ortalama hisse başına elde edilen her 1 TL'lik kar için 5,65 TL ödemeye razı oldukları ifade edilebilir. Buna karşın finansal başarısızlık riski gösteren turizm işletmelerinde ise yatıımcıların ortalama hisse başına elde edilen her 1 TL'lik kar için 0,14 TL ödemeye razı oldukları söylenebilir. Dolayısıyla piyasadaki yatıımcıların finansal anlamda başarısızlık riski taşıyan turizm işletmelerinden beklentilerinin olumsuz olduğunu ve bu bağlamda söz konusu işletmelerin hisse senetlerini satın alma konusunda zayıf düzeyde bir talep gösterdiğini söylemek mümkündür.

Araştırmadan elde edilen bulgular ışığında finansal başarısızlık riski gösteren turizm işletmelerine çalışma sermayesi yatırım düzeylerini ve bu yatırımların uygun finansman kaynaklarını elde ederek likidite durumlarını daha iyi bir noktaya getirmeleri önerilebilir. Burada dönen varlıkların miktarı ve özellikle nakit varlıklar ile finansal varlık yatırımlarının arttırımasının önemli olduğunu söylemek mümkündür. Yine bu işletmelerin hem toplam yabancı kaynak kullanımını hem de kısa vadeli yabancı kaynak kullanımını azaltmaları gerekmektedir. Aktif yapısı duran varlık ağırlıklı olan turizm işletmelerinin bu varlıkların finansmanında öz sermaye ve uzun vadeli yabancı kaynak kullanımına ağırlık vermeleri, finansman risklerini ve çalışma sermayesi intiyaçlarını azaltmaları açısından son derece önemlidir. Ayrıca finansal başarısızlık riski gösteren turizm işletmeleri açısından karılık performanslarını arttırmaları diğer bir ifadeyle negatif kar ve karlılıktan pozitif kar ve karlıığa ulaşmalarının son derece önemli olduğu düşünülmektedir. Sürdürülebilir karlılığın ve nakit akışlarının sağlıklı olabilmesi için bu işletmelerin üretim, satış, genel yönetim ve finansman giderlerini kontrol altına almalarının son derece önemli olduğu düşünülmektedir.

2012-2017 yılları arasında BIST turizm işletmelerinin sayı itibariyle finansal başarısızlık riski taşıyıp taşımama açısından aynı performansa sahip oldukları söylenebilir. Turizm işletmeleri içerisinde finansal başarısızlık riski taşımayan işletme sayısının artmasının Türk turizm sektörü açısından da önemli olduğunu unutmamak gerekir. İşletme yönetimleri için önemli olan konu finansal sıkıntıya girmeden proaktif olarak gerekli önlemlerin alınabilmesidir. Bu araştırmanın en önemli gerçekleştirilme motivasyonlarından birisi de budur. Yukarıda ifade edilen öneriler doğrultusunda turizm işletmelerinin finansal performansının olumlu yönde gerçekleşeceği düşünülmektedir. Bu bağlamda turizm sektöründeki işletme yöneticilerinin finansal başarısızlık risklerini sürekli ölçmelerinin ve finansal başarısızlık riski içerisine girmeden gerekli önlemleri proaktif olarak almalarının bu işletmelerinin hem finansal performanslarını hem piyasa da işlem gören hisse senedi fiyatlarını hem de Türkiye açısından son derece önemli olan turizm sektörünün gelişimini olumlu etkileyeceği düşünülmektedir.

Turizm sektörü ile ilgili literatür tarandığında, özellikle Türk turizm işletmelerinin finansal başarısızlıklarının ölçüldüğü ve finansal başarısızlık riski gösteren ve göstermeyen işletmeler arasındaki finansal performans unsurlarının karşılaştırıldığı herhangi bir araştırmaya tarafımızca ulaşılamamıştır. Bu bağlamda, söz konusu araştırmanın literatürdeki eksikliği gidereceği ve borsada işlem gören Türk turizm işletmeleri bağlamında yatırımcılara ve yöneticilere yararlı bilgiler sunacağı düşünülmektedir. Analizin amacı doğrultusunda kullanılan verilerin ve örneklem kapsamındaki halka açık turizm işletmelerinin sayısının sınırı olması ve uzun yılların analize tabi tutulamaması araştırmanın sınırıııklarını oluşturmaktadır. Gelecek araştırmalarda daha geniş süreyi içeren ve bununla beraber dünya üzerindeki farklı kıtalardaki ülkesel ve alt sektör bağlamında turizm işletmeleri üzerinde analizin tekrarlanmasının daha genellenebilir bulgular elde edilmesi açısından yararlı olacağı düşünülmektedir. Yine anket ya da yüz yüze görüşme yöntemiyle de küçük, orta ve 
büyük ölçekli turizm işletmelerinin verileri toplanarak finansal başarısızlık risklerinin ölçülmesinin turizm işletmelerine ve literatüre fayda sağlayacağı düşünülmektedir.

\section{Kaynakça}

Aksoy, A. ve Yalçıner, K. (2013), İşletme Sermayesi Yönetimi, Ankara: Detay Yayıncılık.

Aktaş, R. (1993), Endüstri İşletmeleri İçin Mali Başarısızlık Tahmini (Çok Boyutlu Model Uygulaması), Ankara: Türkiye İş Bankası Kültür Yayınları.

Akyüz, K. C., Yıldırım, İ., Akyüz, İ. ve Tugay, T. (2017), "Borsa İstanbul'da İşlem Gören Kâğıt ve Kâğıt Ürünleri Sanayi İşletmelerinin Finansal Başarısızlık Düzeylerinin Oran Analizi ve Diskriminant Analizi Yöntemleri Kullanılarak Ölçülmesi”, Düzce Üniversitesi Ormancılık Dergisi,13(1), ss. 60-74.

Altaş, D. ve Giray, S. (2005), "Mali Başarısızlığın Çok Değişkenli İstatistiksel Yöntemlerle Belirlenmesi: Tekstil Sektörü Örneği”, Anadolu Üniversitesi Sosyal Bilimler Dergisi,5(2), ss. 13-28.

Altman, E. I. (1968), "Financial Ratios, Discriminant Analysis and The Prediction Of Corporate Bankruptcy", Journal of Finance, 23 (4), ss. 589-609.

Altman, E. I. ve Hotchkiss, E. (2006), Corporate Financial Distress and Bankruptcy: Predict and AvoidBankruptcy, Analyze and Invest In Distressed Debt, 3rd Edition. New Jersey: John Wiley\&Sons.

Andrew, W. P. ve Schmidgall, R. S. (1993), Financial Management For The Hospitality Industry, USA: AH\&MA.

Aydın, N., Başar, M. ve Coşkun, M. (2014), Finansal Yönetim, Ankara: Detay Yayıncılık.

Beaver, W. H. (1966), "Financial Ratios As Predictors Of Failure", Journal of Accounting Research, 4, ss. 71-111.

Brealey, R. A., Myers, S. C., ve Marcus, A. J. (2001). Fundamentals Of Corporate Finance, The Boston: McGraw-HillCompanies, Inc.

Brigham, E. F. ve Ehrhardt, M. C. (2010), Financial Management Theory and Practice, 13th Edition, USA: South Western Cengage Learning.

Büyükarıkan, U. ve Büyükarıkan, B. (2014), "Bilişim Sektöründe Faaliyet Gösteren Firmaların Finansal Başarısızlık Tahmin Modelleriyle İncelenmesi”, Akademik Bakış Uluslararası Hakemli Sosyal Bilimler Dergisi, (46), ss. 160-172.

Casey, C.ve Bartczak, N. (1985), "Using Operating Cash Flow Data To Predict Financial Distress: Some Extensions", Journal of Accounting Research, 23(1), ss. 384-401.

Ceylan, A. (2001), İşletmelerde Finansal Yönetim, Bursa: Ekin Kitabevi.

Clark, T. A. ve Weinstein, M. I. (1983), "The Behavior Of The Common Stock Of Bankrupt Firms", Journal of Finance, 38(2), ss. 489-504.

DeAngelo, H. ve DeAngelo,L. (1990), "Dividend Policy and Financial Distress: An Emprical Investigation of Troubled NYSE Firms", The Journal of Finance, 35 (5), ss. $1415-1431$.

Diakomihalis, M. (2012), "The Accuracy of Altmans's Models In Predicting Hotel Bankruptcy", International Journal of Accounting and Financial Reporting, 2(2), ss. 96-113.

Elam, R. (1975), "The Effect Of Lease Data On The Predictive Ability Of Financial Ratios", The Accounting Review, 50(1), ss. 25-43.

EulerHermes (2019), "Global Insolvency Outlook 2019", https://www.eulerhermes.co m/en_global/economic-research/insights/Global-Insolvency-Outlook2019-Thecollater al-damage-of-too-low-growth-and-tightening-financial-conditions.html (12.01.2019). 
Fulmer, J. G. (1984), "A Bankruptcy Classification Model for Small Firms", The Journal Of Commercial Bank Lending, 66 (11), ss. 25-37.

Gu, Z. ve Goa, L. (2000), "A Multivariate Model For Predicting Business Failures Of Hospitality Firms",Tourism and Hospitality Research: The Surrey Quarterly Review, 2(1), ss. 37-50.

Hill, N. T., Perry, S. E.ve Andes, S. (1996), "Evaluating Firms In Financial Distress: An Event History Analysis", Journal of Applied Business Research, (12), ss. 60-71.

Hotchkiss, E. (1995), "Post-Bankruptcy Performance and Management Turnover", Journal of Finance, (50), ss. 3-22.

Huo, Y. H. (2006), "Bankruptcy Situation Model In Small Business: The Case Of Restaurant Firms", Hospitality Review, 24(2), ss. 49-58.

İçerli, M. Y. ve Akkaya, G. C. (2006), "Finansal Açıdan Başarılı Olan İşletmelerle Başarısız Olan İsletmeler Arasında Finansal Oranlar Yardımıyla Farklılıkların Tespiti", Atatürk Ûniversitesi Iktisadi ve Idari Bilimler Dergisi, 20(1), ss. 413-421.

İskenderoğlu, Ö. ve Karakozak, Ö. (2013), "2008 Küresel Finansal Krizinin Finansal Oranlar Üzerine Etkisi: BIST'de İşlem Gören İmalat Sanayi İşletmeleri Üzerine Bir Uygulama", Dokuz Eylül Üniversitesi Iktisadi ve Idari Bilimler Fakültesi Dergisi, 28(2), ss. 98-129.

Jagels, M. G. ve Coltman, M. M. (2004), Hospitality Management Accounting, New Jersey: John Wiley \& Sons, Inc.

Jawabreh, O. A., Rawashdeh A. F. ve Senjelawi, O. (2017), "Using Altman's Z-Score Model To Predict The Financial Failure Of Hospitality Companies-Case Of Jordan", International Journal of Information, Business and Management, 9(2), ss.141-157.

Kalaycı, Ş. (2014), SPSS Uygulamalı Çok Değişkenli İstatistik Teknikleri, 5. Baskı, Ankara: Asil Yayın Dağıtım.

Kamuyu Aydınlatma Platformu (2019), “BIST'te İşlem Gören Lokanta ve Oteller Sektör Şirketleri”, https://www.kap.org.tr/tr/Sektorler (05.01.2019).

Kandır, S. Y., Karadeniz, E., Özmen, M. ve Önal, Y. B. (2008), "Türk Turizm Sektöründe Büyüme Göstergelerinin Turizm İşletmelerinin Finansal Performansına Etkisinin İncelenmesi”, Dokuz Eylül Üniversitesi Sosyal Bilimler Enstitüsü Dergisi, 10 (1), ss. 211-237.

Karadeniz, E., Unur, K., Köşker, H. ve Zencir, B. (2015), “Van İlinde Faaliyet Gösteren Kobi Statüsündeki Konaklama ve Seyahat İşletmelerinin Finansal Sorunlarının Analizi”, Çukurova Üniversitesi Sosyal Bilimler Enstitüsü Dergisi, 24(1), ss. 8598.

Karadeniz, E., Dalak, S., Beyazgül, M. ve Günay, F. (2016), "Turizm Alt Sektörlerinin Finansal Performanslarının Oran Yöntemiyle Karşılaştırmalı Analizi”, Muhasebe Denetime Bakış Dergisi, 16(49), ss. 49-68.

Karadeniz, E., Koşan, L. ve Kahiloğulları, S. (2014), "Borsa İstanbul'da İşlem Gören Spor Şirketlerinin Finansal Performansının Oran Yöntemiyle Analizi”, Çukurova Üniversitesi Sosyal Bilimler Enstitüsü Dergisi, 23(2), ss. 129-144.

Legault, J.C.A. (1987), "CA-Score, A Warning System For Small Business Failures", Bilanas, ss. 29-31.

Muzır, E. ve Çağlar, N. (2009), "The Accuracy Of Financial Distress Prediction Models In Turkey: A Comparative InvestigationWith Simple Model Proposals", Anadolu Üniversitesi Sosyal Bilimler Dergisi, 9(2), ss. 15-48

Ohlson, J. A. (1980), "Financial Ratios and The Probabilistic Prediction Of Bankruptcy", Journal of Accounting Research, 18(1), ss. 109-131.

Özdemir, F. S. (2011), Finansal Raporlama Sistemlerinin Bilginin İhtiyaca Uygunluğu Açısından Değerlendirilmesi: IMKB Şirketlerinde Finansal Başarısızlık Tahminleri Yönüyle Bir Uygulama, Yayınlanmamış Doktora Tezi, Ankara Üniversitesi, Sosyal Bilimler Enstitüsü, Ankara. 
Özdemir, F. S. (2014), "Halka Açık ve Halka Açık Olmayan İşletmeler Yönüyle Tekdüzen Muhasebe Sistemi ve Altman Z Skor Modellerinin Uygulanabilirliği”, Ege Akademik Bakış, 14, ss. 147-161.

Poyraz, E. ve Uçma, T. (2006), "Türkiye'de Faaliyet Gösteren İhracatçı Sektörlerin Mali Kriz Ortamlarında Finansal Başarısızlıklarının Altman Z-Skor Modeli Yardımıyla Ölçülmesi", Muhasebe ve Finansman Dergisi, (32), ss. 1-10.

Selimoğlu, S. ve Orhan, A. (2015),"Finansal Başarısızlığın Oran Analizi ve Diskriminant Analizi Kullanılarak Ölçümlenmesi: BIST'de İşlem Gören Dokuma, Giyim Eşyası ve Deri İşletmeleri Üzerine Bir Araştırma", Muhasebe ve Finansman Dergisi, (66), ss. 21-40.

Springate, G. L. V. (1978), "Predicting The Possibility Of Failure In A Canadian Firm", Master'sThesis, Simon Eraser University.

Türk, Z. ve Kürklü, E. (2017), "Financial Failure Estimate In BIST Companies With Altman (Z-Score) and Springate (S-Score) Models", Osmaniye Korkut Ata Üniversitesi Iktisadi ve Idari Bilimler Fakültesi Dergisi, 1(1), ss. 1-14.

Türksoy, A. (2007), "Konaklama İşletmelerinde Mali Başarısızlığa Yol Açan Etmenler", Ege Akademik Bakış, 7(1), ss. 99-115.

Unur, K. (2000), “Turizmin Türkiye'nin Ödemeler Dengesine Etkisinin Analizi”, Dokuz Eylül Üniversitesi Sosyal Bilimler Enstitüsü Dergisi, 2(3), ss. 1-17.

Unur, K. (2004), "Turizmin Ekonomik Etkilerinin Ölçülmesi”, Dokuz Eylül Üniversitesi Sosyal Bilimler Enstitüsü Dergisi, 6(4), ss.114-142.

Warner, J. B. (1977), "Bankruptcy Costs: Some Evidence", Journal of Finance, 32, ss. 337-347.

Weibel, (1973), The Value Of Criteria To Judge Credit Worthiness In The Lending Of Banks, Bern/Stuttgart Quoted In Choi F.D.S., International Finance and Accounting Handbook, 3rd Edition, USA:Wiley\&Sons.

White I. G., Sondhi, C.A. ve Fried, D. (1997), The Analysis and Use Of Financial Statements, New York: John Wiley \& SonsInc. 